\title{
The Preservation of Albanian Tongue (Shqip) Since the Beginning
}

\author{
Saimir A. Lolja \\ Faculty of Natural Sciences, University of Tirana, Blvd. Zogu I, Tirana 1001, ALBANIA \\ Corresponding Author: Saimir A. Lolja, E-mail: slolja@hotmail.com
}

\section{ARTICLE INFO}

Article history

Received: September 10, 2019

Accepted: November 18, 2019

Published: December 31, 2019

Volume: 10 Issue: 6

Advance access: December, 2019

Conflicts of interest: None

Funding: None

Key words:

Idiom,

Nephilim,

Speech,

Shqip,

Albanian,

Pelasgian,

Arbëresh

\begin{abstract}
In the beginning, humans had a tongue (gjuhën, Shqip). Then, they could or couldn't let go of the tongue (len ...gjuhën, Shqip). Albanian natural tongue (Shqip) implies the use of the tongue in the mouth for articulating (shqiptoj, Shqip) words. The eternity of Shqip (Speech) is in its words that are wordy clauses, phrases, parts of or short sentences. The Speech (Shqip) and other lan...guages (len...gjuhët, Shqip) carry these kinds of wordy clauses to prove the permanency of Shqip.The Speech (Shqip) had local and schooled forms in distant antiquity. Therefore, various types of writing appear now. Since the schooled style was in general use and carried later in the papers and books of lan...guages (len...gjuhëve, Shqip), it has been preserved unchanged. Its pieces, no matter how small are, every time get easily read and quickly understood using contemporary Shqip.The Speech (Shqip) was the first stratum in the Euro-Mediterranean area. It was the Speech (Shqip) of Nephilims (Nëfillimëve). The Shqip of today can be used to read and understand both words in other idioms and ancient writings.
\end{abstract}

\section{INTRODUCTION}

Both connected facts and reason are needed to go to the truth because lone pieces of evidence are not enough. Moreover, the elements of the past loose value when specific reading and understanding have deliberately been assigned to them. Therefore, the research needs scientific logic as a tool for knowing. A logical truth is an assertion that remains true under all angles of view and proves only naturally. Gottfried Wilhelm Leibniz (1646-1716) concluded that the truth of reasoning, its reason or explanation can be discovered by analysis of the notions or concepts. Then, resolving it into more straightforward ideas and simpler truths until reaching the primitives. (Look, 2013; Gómez-Torrente, 2018)

The Speech (Shqip) is incorrectly referred to as Albanian "lan...guage" instead of the Albanian tongue. A fogginess in knowledge, understanding, and perception of the past comes across in respect with Albanians (Shqiptarët) and the Speech (Shqip). The obscurity starts with the fact that the speakers of the Speech call themselves Shqiptarë, whereas the foreigners call them Albanians. The ambiguity becomes much denser from the confusion brought by the mainstream narration of the distant past only with shifts of invading populations that eradicate the previous population, denial of native peoples, consideration of the antiquity as a primitive epoch, and interpretation of things or objects only from the religious viewpoint. Therefore, the issue is not whether there were or were not Shqip and Shqiptare in the distant past. It is the fact that the distant past is not fully illuminated and that implies the necessity to enlighten the Albanian, Mediterranean, and European history.

Therefore, this research aims to examine through facts, reasonings, and comparisons the extent of the Speech (Shqip) in the past. Because this study analyses the Speech through very long times of the past, the scientific approach will be untraditional. The investigation starts with the history of Dark Ages and that of Byzantine script. It puts in use the scientific foundations of lin... guistics, the Speech (Shqip) of today, old holy books, toponyms, and Latin, Byzantine, and English idioms. The connecting keys in the research are the words and wordy clauses, phrases, and parts of or short sentences that exist and make sense only in the Albanian tongue (Shqip). The proofs come from the Speech (Shqip) itself, published research of other authors, nature, geographical features, and known historical past.

\section{DARK AGES}

The first was the Dark Ages of the centuries $\mathrm{V}-\mathrm{XV}$ that covered Europe. It began with the publication of the book 
Mythologice by Fabius Planciades Fulgentius in the century V. (Fabius Planciades Fulgentius, Wikipedia, 2019) The darkness began with the obliteration of all Roman schools, universities, libraries, and books. It commenced with the Edict of Milan in 313 A.D. for transforming the Roman Empire to Christian empires of the West and East. The Western Roman Empire ended in 476 A.D. while the Eastern Roman Empire lasted until 1453. In the new conditions, there were only monasteries and churches, which had monks and priests who were the only ones that could read and write. The division of the Roman Empire and the end of its Western side only intensified the darkness.

The Latin word Mythologice translates to "The Science of Lie" in English. That book was one of the leading resources for monks to eradicate the public memory of the near past and feed the thinking with the untrue perception of ancient times. In churches, the priests advised uneducated crowds what to know and how to think based only on the sayings from the Bibles. The tiniest spark of a different thought was called heresy and the Inquisition in the centuries XII - XIX punished the person with tortures and burning at stake.

The European Renaissance started in the century XIV. To refresh Mythologice or The Science of Lie in the new conditions, the Italian author Natalis Comes published the ten-volume book Mythologiae in 1567 in Venezia. (Natalis Comes, Wikipedia, 2019) That book with the same title provided the same service. Since its publication, it became the reference point for Classical Mythology. It was the tool to keep eradicated the accurate public memory for new generations about the antiquity and swap it with the incorrect perception.

There was enough time in the centuries $\mathrm{V}-\mathrm{XV}$ to destroy books, schools, and libraries, to erase the public and scholars' memories, to flatten towns, castles, roads, and civilizations, to cover sites and traces with soil, to exterminate peoples in high numbers, and to change the names of people and places. Simultaneously, plenty of time was available to rewrite many times some books based on cautious requests and to write a few new ones. And, always making those books have religious nuances and contents.

The second was the Darkness of the centuries XV - XIX that covered the Illyric Peninsula when the Ottoman Empire occupied it. In the century XX, it continued for inertia and got thickened by Slavic Communist darkness. The Darkness of the centuries XV - XX that plagued the Albanian lands either preserved the thick layer of Byzantine Darkness or thickened the latter with Arabic Ottoman and Slavic Communist layers. What had remained undemolished and not scorched from the first Darkness was complemented in the second Darkness. Besides, the perceptive distortion of the past was educated in the century XX.

\section{AN EASTERN CONFUSION IN PERCEPTION}

The Roman Empire that officially started in the year of 27 B.C. had the Latin lan...guage as the unifying and communication lan...guage. The Western Christian Roman Empire until 476 A.D. and the western churches afterward preserved the Latin for the religious books, which were also the only ones allowed in circulation.

The Byzantine theologians, brothers Cyril and Methodius, restructured the Glagolitic Alphabet in 863 A.D. (Xharra,
2019) Through adjustments in time and regions, it took different forms and got used in eastern churches. The Eastern Christian Roman Empire completely detached itself from the West in the year of 1054 and interrupted the use of Latin script.

The Ecumenical Patriarchate of Constantinople established its Byzantine script accordingly also by extracting pre-Latin alphabetic letters from the Mediterranean Basin; much from the Illyricum stratum. (Xharra, 2019) Additionally, while the Latin words in the West used the suffix -us, the Byzantine script in the East distinguished its words by the suffix -os. Being entirely separated from Latin script, it became the official script for the Eastern Christian Roman Empire. The latter existed until the year of 1453.

In 1830, the British, French, and Russian empires created a religious principality named "Greece". It had an area equal to $1 / 6$ of modern Greece. Being a religious state and essentially a mirror of the ex-Eastern Christian Roman Empire, the Ecumenical Patriarchate of Constantinople assigned its Byzantine script as the official lan...guage to "Greece".

The British Empire chose the flag of the year 1700 of the British East India Company for the flag of the priestly principality named "Greece". The color had to change only from red to blue since the flag had the cross for the priestly principality named "Greece". (East India Company, Wikipedia, 2019)

Consequently, and due to the propaganda circulated by the fans of an "ancient Greece", a confusion in perception occurred: since the new state was called "Greece", its official lan...guage was mistakenly named "Greek". And intentionally and misguidedly, the fans of "ancient Greece" and those self-named "Greeks" by flying back in time called and still call as "Greek" all the Roman Eastern Empire and all the pre-Roman history.

The Eastern Christian Orthodox priests were the writers, speakers, spreaders, and teachers of the new lan...guages for the populations they shepherded. In "Greece", the speech of the people differed from that of the church. The people were Albanians (Eng.) - Arbanas (Shqip) - Arbanites Arvanites (biz.), and its speech was Shqip. And as of today, the native population and especially the elderly speak Shqip. Both under the Eastern Christian Roman Empire and the Ottoman Empire, the people of current Greece spoke Shqip and were called or called themselves Romans, Romaioi or Romioi. But the propaganda emanating in the century XIX from European empires made up the fairy-tale of an "ancient Greece populated by beautiful, tall, blond, wise people, representing perfection". And tying that "ancient Greek" fairy-tale to the native Albanian population, it termed that indigenous Albanian population a "Greek" population. (Kimmelman, 2009)

And, it means that there was no "Greek" or "Helen" nation; there were never. In reading the written history and seeing on the past maps, there is no encounter ever with any state named "Greece" or "Hellas" and "Greeks" or "Helens". Moreover, there was never any "Greek" Empire or Emperors. In all the periods of the Roman Republic and Empire, there was never any region or province named "Greece" or "Elláda". The encounter is with the names of Illyria, Prefecture of Illyricum, Macedonia, and Epirus, but not "Greece" or "Elláda". (Roman Province. Wikipedia, 2019) 
Only between the end of century VII and the end of century XII, there was a Byzantine province called "Theme of Hellas", which encompassed parts of present Greece. Its name was random, and its establishment was only for Byzantine military purposes against Slavic herds. It had no cultural and verbal connections with native people who were Albanians - Arbanas - Arbanites - Arvanites - Shqiptarë. (Hellas theme, Wikipedia, 2019)

The Eastern Christian Roman Empire was a Christian Orthodox Roman Empire and not a "Greek" empire. Its emperors originated from different countries, e.g., Illyria, Syria, Bulgaria, etc. When a state with the Imperial Latin as the official lan...guage would have come into view, would the population of that state be called the Latin nation with Latin as the national lan...guage?

Besides, there were by name, e.g., no ancient Italy, Albania (Shqipëri), Germany, Britain, France, Turkey, or Egypt. The places and populations got organized differently, and their names were unlike today. For example, contemporary Egypt was called Nubia. This means, the existence of an "ancient Greece" makes no sense.

In the past two centuries, many ancient writings carved on stone and pottery have been claimed to represent the "ancient Greek" lan...guage. The Byzantine lan...guage, that is the Greek lan...guage, does not help to read, pronounce and understand the desired "ancient Greek" lan...guage. The forms, functions, and the ordering of the words (the grammar) and the composition of clauses, phrases, and sentences (the syntax) of the "ancient Greek" lan...guage make no sense to the present-day Greek speakers, independently that some letters might look similar.

\section{THE LIN...GUISTICS AS A SCIENCE}

The evidence to prove how old is a written idiom is either the writing on stones or old books. The lin...guistics as science started in the second half of the century XIX. Like any other branch of science, the quality of research in lin...guistics depends on the truthfulness of experimental data, the quality of measuring tools, the angle of view, and the intention of the study.

The fundamental scientific pillars of lin...guistics are the following: (1) Grammar - the rules for composing of clauses, phrases, and words. (2) Morphology - the study of root and parts of the word, and its relationship to other words. (3) Syntax - the rules for building sentences; (4) Phonology - the study of the connection between sounds and signs. (5) Semantics - the accepted meaning for phrases, words, and signs and symbols. (6) Pragmatics - the study of the link between context and purpose, and how the definition is transmitted. (7) Anthropology - the study of speech as a social need and part of social culture.

\section{FIRST HAVE THE SPEECH (GJUHËN), THEN LAN...GUAGE (LEN...GJUHËN) OR NOT}

In the beginning, humans had a tongue (gjuhën, Shqip). Then, some couldn't let go of the tongue while others did. The speaking is physically enacted by utilizing the tongue (gjuhë, Shqip; sermon, Lat.) in the mouth. Therefore, in Shqip (Speech), it is said: "Ai flet gjuhën..." (He speaks the tongue...). That is: He speaks using the tongue or pronounces (shqipton, Shqip) by putting in use the tongue that nature programmed for that purpose. And, who has left the tongue (lënё...gjuhën, Shqip; lin...gua, lat.; lan...guage, Eng.) speaks the lin...gua or lan...guage (len...gjuhën or lin... gjuhën, Shqip). It means that someone should first have the tongue (gjuhë, Shqip) and then can let it go (len...gjuhën, Shqip) or not.

This is proof that Shqip has been the first or sprouted before lan...gauges, other lexicons. Said through an example, there were first the Shqip names Gjon and Gjergj, and then the non-Shqip names Giánnis and Geórgios or John and George came out. Because, otherwise both names Gjon and Gjergj and Janis and Jorgios, and Xhon and Xhorxh would have been in Shqip.

It is in line with the conclusions in the book by Prof. Luigi Luca Cavalli-Sforza (Cavalli-Sforza, 2000). Wherein, Figure 13, page 164, presents the Shqip (Speech) as the oldest idiom with age more than 9000 years. That is, the Shqip was the first sprouted speech compared to the other lan...guages of the Euro-Indian model; see Figure 1. (Cavalli-Sforza, 2000)

The Ice Age in Europe is estimated 25'000-13'000 years ago. The archaeological findings have shown that after the Ice Age the life began to recover. About 10’000 years ago, people began to farm the soil. That is, the farmers (pjellargët, tokarët, arbërësit, arbëreshët, arbanasit, Shqip) began to reconvert the earth to arable land. So far, in contemporary Shqip, the person hired to plough and cultivate the arable land is called "argat". It is true because the national culture, including the Speech and the art of folk dressing, is genetically inherited. (Cavalli-Sforza, 2000) Also, the word "pjellargët" in Shqip is misspelled and put in use from non-Albanian sources as "pellazgët" in Shqip or "Pelasgians" in English.

The spoken idioms are like the flowers of life that sprout out of a single or a common stratum. This angle of view is in harmony with the ancient wisdom of the Flower of Life on Earth. Geometrically, the Flower of Life displays the full compatibility of the proportions that it contains. It can be extracted from it the Tree of Life, Egg of Life, Seed of Life, Fruit of Life, the sphere, the Platonic solids, the Golden Ratio, Sacred geometry, etc. (Flower of Life, 2019) This has explanation through a natural analogous example. The flower Narcissus poeticus is classified within the Amaryllis family, and this does not mean that Narcissus poeticus has been born, e.g., from the flower Amaryllis belladonna.

\section{CARRIED IN ITS IDIOM}

The last two millenniums of invasion of the Albanian lands from Roman and Ottoman Empires were enough to erase or cover nearly every trace of written Shqip on paper or stones. However, the Shqip (Speech) has a characteristic that makes it everlasting, no matter how minor it appears communicated anywhere. In the past and today, both in speaking and writing, the Speech (Shqip) contains many words that themselves are simple clauses or sentences with a clear 


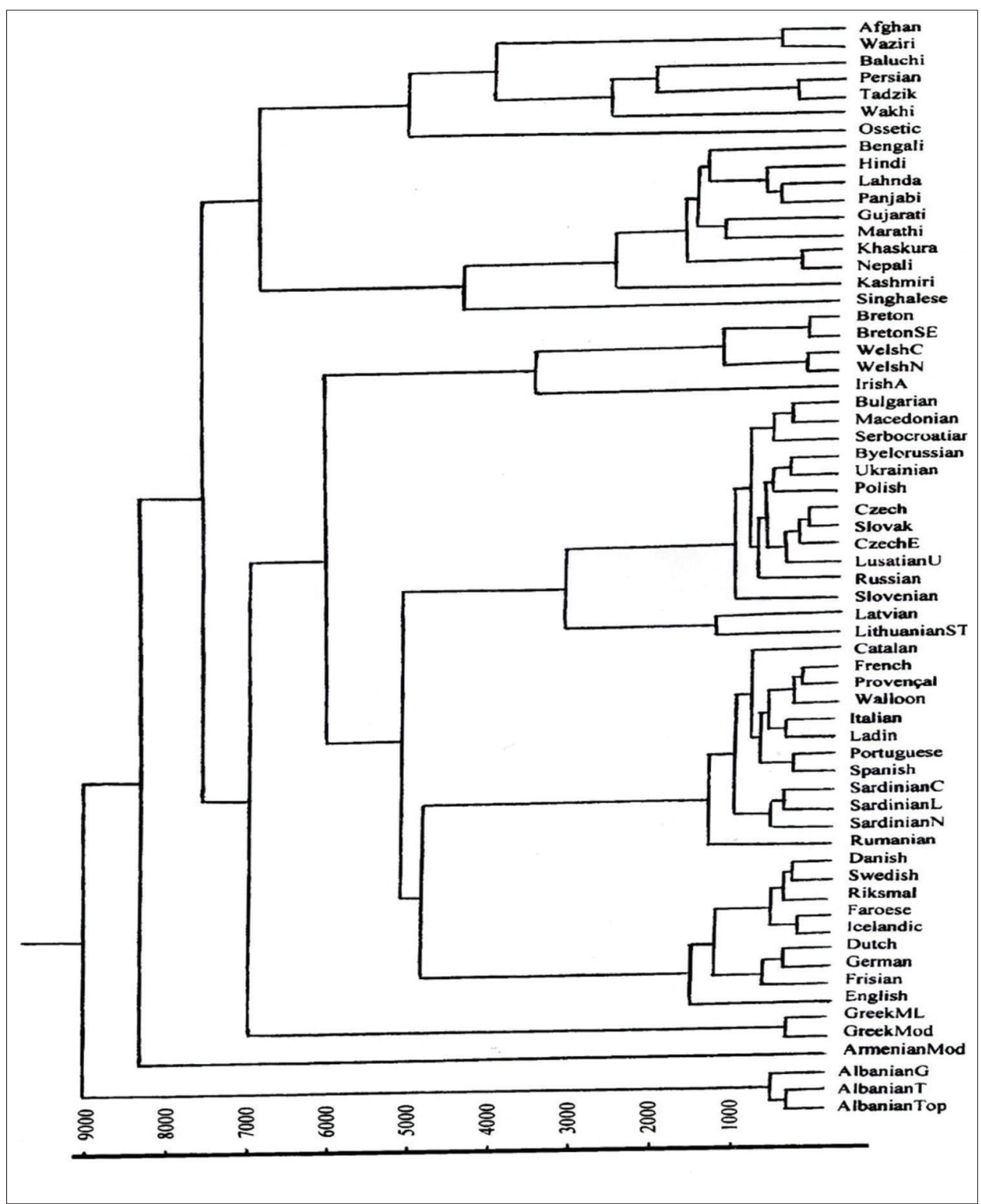

Figure 1. The tree of idioms. (Cavalli-Sforza, 2000, p. 164)

understanding in terms of Grammar, Morphology, Syntax, Phonology, Semantics, Pragmatics, and Anthropology. Only a native Albanian (Shqiptar) can distinguish them easily. Some examples are in Table 1.

\section{THE SEARCH IN LAN...GUAGES}

The characteristic of Speech (Shqip) of having wordy clauses with real and complete meaning has preserved it unchanged forever. That is, even if books and scripts in Shqip get destroyed, the inherited spoken Speech, words, and wordy clauses carried in lan...guages are enough to rebirth or revive a wide-ranging Shqip.

The Albanian words and wordy clauses come across in lan...guages of at least continental Europe and Mediterranean Basin as part of the vocabulary and place names (toponyms). Such a presence proves that the noticed fragments of Shqip:

(1) Have been left forgotten and uncovered along with history, and thus have been kept unchanged. The cases analyzed in the coming section 9. Carried in Toponyms confirm this saying.
(2) Or have been taken in use every time due to their respective accurate, expressive contents.

(3) Or have been chosen in an altered form, but the original word is every time conserved.

(4) Or, even if those fragments have been put in use by later lan...guages, it proves a much earlier presence of Shqip and a well-developed and leading civilization speaking Shqip (Speech), speaking the Divine Speech.

The Speech (Shqip) of today has in use non-Albanian words that have entrapped randomly or by force along the past 2000 years of foreign invasions. And yet, the Shqip idiom has not changed because it adjusts them in Albanized forms. The presence of Shqip-reading words and wordy clauses in the lan...guages of continental Europe and Mediterranean Basin, and beyond:

(1) Omits the possibility of import of pieces in Shqip from other lan...guages, because the Shqip speakers have not been invading newcomers for all other populations.

(2) Proves that Shqip speakers have been native people at least in continental Europe and the Mediterranean Basin, 
Table 1. Examples of wordy clauses in Shqip

\begin{tabular}{llll}
\hline Shqip & Broken down & Latin & English \\
\hline Pjellar & Pjell ar & Facite ergo arabilis et & I produce arable land. \\
Pjellarg & Pjell ar-g & Qui facit terram arabilem & He who produces arable land. \\
Arbëra & Ar bëra & Ego feci terram arabilem & I made arable land. \\
Arbana & Ar bana & Ego feci terram arabilem & I made arable land. \\
Arbër / Arbëresh & Ar bër [ës] & Qui facit terram arabilem & He who makes arable land. \\
Arbërës & Ar bër ës & Illi qui faciam terram arabilem & They who make arable land. \\
Arbëria & Ar bër ia & Dominium Arbëreshes, qui agricolae terram & The dominion of Arbëreshes, of land farmers. \\
Tokare & Tok(ë) ar e & Arabilis & Arable land \\
Gadishull & Gati ishull & Paene insula & Almost an island \\
Humbner(ë) & Humb në er(ë) & Evanescet in aere / ventum [in abyssum irent & Disappear in air/ wind [in the abyss] \\
Ilir & I lir(ë) & Liberi & Free \\
Iliri & I liri & Liberus & The free (masc.) \\
Elira & E lira & Libera & The free (fem.) \\
Saimir & Sa i mir(ë) & Quam bonum & How good (masc.) \\
Samir & Sa mir(ë) & Quam honestus & How well \\
\hline
\end{tabular}

and always present among scholars. For instance, the first farming settlers known in Latin records as Tochari (Tokarë, Shqip; Tocharians, Eng.) in the centuries XX B.C. - VIII A.D. in the Tarim Basin in western China were European by race. (Carling, 2018; Tocharians, Wikipedia, 2019). Their description was in Shqip: Tok(ë) ar-ë (Of the arable land, Eng.). The present-day connection to Tocharians is the Hunza people, who live in the Hunza Valley, in Pakistan, nearby the Tarim Basin. By race, they are European. By the culture, they resemble Albanians. Their idiom has kept alive many words, short sentences, and wordy clauses of the Albanian tongue (Shqip). (Hoffman, 1985; Tiffou, 1993; Lolja, 2003)

(3) Exhibits that there have been ahead of time an advanced Shqip-speaking civilization out of which lexicon pieces had been borrowed later for lin...guistic compositions.

(4) Proves that the shift from the Speech (Shqip) to lan... guages has had conserved their grammatical roots by carrying frozen those words and wordy clauses in Shqip. It so explains the fundamental compliance between the Speech (Shqip) and English words given in Table 2.

\section{CARRIED IN THE BIBLES}

The first Bible is the Hebrew Bible, known as Tanakh in Hebrew, in which the collection of ancient religious writings gets arranged in 24 books. It comes into three parts: Torah ( 5 books), Nevi'im (8 books), and Ketuvim (11 books). The Old Testament is the first part of Christian Bibles and has been written based on the Hebrew Bible. (Hebrew Bible, Wikipedia, 2019; Old Testament, Wikipedia, 2019)

The first book in Torah is called Bereishit (Hebr.) or "In the beginning," and it is named Genesis in the Old Testament. The word "Bereishit" sounds like a wordy clause in Shqip because Bereishit $=$ Bërë ishit $/$ sit $($ Shqip) $=$ Made $[$ you $]$ were / The Doers (Eng.). Moreover, the making of nature and life gets described at the beginning of this first book. (Book of Genesis, Wikipedia, 2019) The Hebrew Calendar considers the origin of existence in the year 3761 B.C. The following reads in this book of creation (English Standard Version Bible, 2004; Orthodox Jewish Bible, 2004):

Genesis 1:1 - In the beginning, God created the heavens and the earth.

Genesis 6:4 - The Nephilim were on the earth in those days, and also afterward when the sons of God came into the daughters of man, and they bore children to them. These were the mighty men who were of old, the men of renown.

Genesis 11:1 - And the whole earth was of one tongue and one speech.

Genesis 11:6 - And the Lord said, "Behold, they are one people, and they have all one speaking, and this is only the beginning of what they will do. And nothing that they propose to do will now be impossible for them".

The fourth book in Torah is called Bamidbar (Hebr.) or "In the desert", and in the Old Testament, it is named "Numbers". The following is written in it (English Standard Version Bible, 2004; Orthodox Jewish Bible, 2004):

Numbers 13:33 - And there we saw the Nephilim (the sons of Anak, who come from the Nephilim), and we seemed to ourselves like grasshoppers, and so we seemed to them.

Referring to Grammar, Morphology, Syntax, Phonology, Semantics, Pragmatics, and Anthropology, and considering its placements and use in the book, the word "Nephilim" is a wordy clause in Shqip. The word "Nephilim" (plural Nëfillimët, Shqip) is in the beginning (Në fillim, Shqip) of narration in the first book of Genesis, at the beginning of the beginning (nё fillim tëfillimit, Shqip) of Creation. It is recited in the fourth book as well. The position of this word is right at where and when the people in the beginning (në fillim, Shqip) of the creation of life on Earth got described. That is, it conveys the people of the beginning, the beginners - the Nephilim - nëfillimët (Shqip). In the beginning (Në fillim, Shqip), all people spoke one speech, the Speech (Shqip) of Nephilim (plural Nëfillimëve, Shqip). 
Table 2. Compared words for every letter of the Albanian (Shqip) Alphabet

\begin{tabular}{|c|c|c|c|c|c|}
\hline Nr. & Alb. letter & Eng. word & Alb. word & Latin & Byzantine or current Greek \\
\hline 1 & $\mathrm{~A}$ & Uncle & Ungj & Patruus & Thios \\
\hline 2 & $\mathrm{~B}$ & Bull & Bull & Taurus & Tavros \\
\hline 3 & $\mathrm{C}$ & Its & I tij / saj & Eius & Tou \\
\hline 4 & Ç & Chick & Çikë & Puella & Kopella \\
\hline 5 & $\mathrm{D}$ & Door & $\operatorname{Der}(\ddot{e})$ & Ostium & Thira \\
\hline 6 & DH & That & Atë & Quod & Afto \\
\hline 7 & $\mathrm{E}$ & Eight & $\operatorname{Tet}(\ddot{\mathrm{e}})$ & Octo & Okto \\
\hline 8 & $\ddot{\mathrm{E}}$ & Per & Për & Per & $\mathrm{Ja}$ \\
\hline 9 & $\mathrm{~F}$ & Flock & Flok & Gregem & Mali \\
\hline 10 & G & Gurgle & Gurgulloj & Singulto & Kelaryzo \\
\hline 11 & GJ & Legion & Legjion & Legio & Legeonas \\
\hline 12 & $\mathrm{H}$ & Hunger & Hangër & Fames & Pina \\
\hline 13 & I & Languish & Lëngoj & Aegroto & Eksastheno \\
\hline 14 & $\mathrm{~J}$ & I am & Iam & Ego sum & Ime \\
\hline 15 & $\mathrm{~K}$ & Dark & $\operatorname{Dark}(\mathrm{e})$ & Tenebrosi & Vradhi \\
\hline 16 & $\mathrm{~L}$ & Light & I leht(ë) & Levis & Elafros \\
\hline 17 & LL & Pull & Tërheq & Attrahendam & Elko \\
\hline 18 & M & Major & Madhor & Major & Mizon \\
\hline 19 & $\mathrm{~N}$ & Night & $\operatorname{Nat}(\ddot{e})$ & Nocte & Nihta \\
\hline 20 & $\mathrm{NJ}$ & Onion & Qep(ë) & Cepa & Kremidhi \\
\hline 21 & $\mathrm{O}$ & Copy & $\operatorname{Cop}(\ddot{e})$ & Exemplum & Antigrafo \\
\hline 22 & $\mathrm{P}$ & Plough & Plug & Aratrum & Arotro \\
\hline 23 & Q & Stockyard & Vath(ë) & Stabulatio & Stani \\
\hline 24 & $\mathrm{R}$ & Desire & Dëshir(ë) & Cupiditas & Thelisi \\
\hline 25 & $\mathrm{RR}$ & Narrow & I ngusht(ë) & Angusta & Stenos \\
\hline 26 & $\mathrm{~S}$ & Super & Sipër & Eximius & Yper \\
\hline 27 & SH & Shawl & Shall & Palliolum & Salli \\
\hline 28 & $\mathrm{~T}$ & Trunk & Trung & Truncus & Kucuro \\
\hline 29 & TH & Three & Tre & Tres & Tria \\
\hline 30 & $\mathrm{U}$ & You & $\mathrm{Ju}$ & Vos & Esis \\
\hline 31 & $\mathrm{~V}$ & Vine & $\operatorname{Ven}(\ddot{e})$ & Vinum & Inos \\
\hline 32 & $\mathrm{X}$ & Adze & Sqepar & Tondeo & Skepari \\
\hline 33 & $\mathrm{XH}$ & Jacket & Xhaket(ë) & Paenulam & Sakaki \\
\hline 34 & $\mathrm{Y}$ & Étude (fre.) & Studim & Stude & Spudi \\
\hline 35 & $\mathrm{Z}$ & Zeal & Zell & Zelus & Zillos \\
\hline 36 & $\mathrm{ZH}$ & Vision & Fushpamësi & Visio & Orama \\
\hline
\end{tabular}

The titles of the second and third parts of the Hebrew Bible are Nevi'im (Hebr.) or Prophets (Eng.) and Ketuvim (Hebr.) or Writings (Eng.). Both these titles sound in Shqip because both are read clearly in Shqip, and both give accurate meaning for what they represent as titles and contents in Hebrew. The eight books of Nevi'im are the books of (We!) the Prophets, sayings of whom come (Where?) in their writings.

Nevi'im = Ne vim - Ne vijmë - Ne [profetët] vijmë (Shqip) $=$ We [the prophets] come (Eng.)

Ketuvim = Këtu vim - Këtu vijmë - Këtu [në këto shkrime] vijmë (Shqip) $=$ Here [in these writings] we come (Eng.)
The Book of Mormon is a sacred manuscript of the Latter-Day Saint movement comparable to the Bible. It got originally published in March 1830 in the USA. At the beginning of the book, there are mentioned two sacred stones called Urim and Thummim attached to the breastplate of ancient seers. (Smith, 2013) The words Urim and Thummim are encountered seven times in the Old Testament. (Urim and Thummim, Wikipedia, 2019)

There is no definite explanation and understanding of these two words from those who are not Albanians. Referring to Grammar, Morphology, Syntax, Phonology, Semantics, Pragmatics, and Anthropology, these two words are purely 
in Shqip: Urim and Thummim/Thumim/Thumbim. Every Albanian (Shqiptar, Shqip) can easily read and understand each word and smile. It is so also because it makes sense viewing life as a Wish (Urim, Shqip) and a Sting (Thumim/ Thumbim, Shqip), as satisfaction and dissatisfaction, as a like and a dislike.

Speaking Shqip (Speech) means to express the holy tongue, the Sacred Shqip (Holy Speech), the Divine Breath, the Holy Word, the Celestial Speech, the First Voice because it was first the voice, then life began.

\section{CARRIED IN TOPONYMS}

The following are several examples where the wordy clauses in Shqip got preserved in place names (toponyms). Referring to Grammar, Morphology, Syntax, Phonology, Semantics, Pragmatics, and Anthropology, these place names are wordy clauses in Shqip (Speech). These illustrations are noteworthy because they have the proof by the very natural physical characteristic of their respective places. This view goes beyond the simple questions of the origin or roots of the words (etymology) and places names (toponyms). The following cases deal just with the bearing and preservation of the wordy clauses in Shqip in the areas now covered by lan... guages.

Mar Mediterraneo (Ita.) - Deti Mesdhe (Shqip) - Deti Mes dhe - The resources give different historical names for the Mediterranean Sea. Its actual name appeared in a document authored by a Spanish scholar of the century VI. (Mediterranean Sea, Wikipedia, 2019) As seen from space, "Deti Mes-Dhe" in Shqip is "Deti në Mes të Dheut" (The Sea in the Middle of the Earth).

Aigaío Pélagos (Biz.) - Ege Denizi (Turk.) - Mar Egeo (Ita.) - Deti Egje (Shqip) - This is the sea with many islands between Turkey and Greece. In books, a nonsense fairytale from antiquity has dressed the origin and meaning for the name of this sea. (Aegean Sea, Wikipedia, 2019) Since this sea is part of the great Mediterranean Sea (Deti Mesdhe, Shqip), the local people on the islands and continent, namely Arbanas, Arbanites (Arvanites, Biz.), called it "Deti Mesogjë" (Shqip). This name is a wordy clause in Shqip that describes the trait of this sea because it qualifies "Detin Meso-gje" (Shqip), the Sea that is in the middle [of the soil]. And naturally, the name of the sea in the Speech (Shqip) of local peoples took the form "Deti Egje" and had other silhouettes in the lan...gauges.

Malta (Eng.) - Maltha - Mal tha (Shqip) - Dry Mountain Malta is an island in the Mediterranean Sea. Malta is precisely a barren rocky island, where there are no permanent rivers and lakes except in heavy rains. (Malta, Wikipedia, 2019) Maltha or Mali $i$ Thatë (Shqip) - Dry Mountain is a common toponym on the Albanian lands in the Illyric Peninsula.

Gibraltar (Eng.) - Gjibrrylthari - Gji brryl thari (Shqip) - The Bay of the Dry Elbow - Gibraltar is a British overseas city-state, bordering Spain. It is the eastern cape of the Bay of Gibraltar or Bahía de Algeciras (Spa.). (Gibraltar, Wikipedia, 2019) Seen from very high above the Earth, the form of the Cape resembles a turned elbow, where the inner side is the port of Gibraltar or Gji-brryl-tharit (Shqip). And almost the entire Cape is covered by the Rock of Gibraltar, which is a dry monolithic limestone promontory. Better saying, it is a dried rock since it is mostly limestone. That is, what is known as the Bay of Gibraltar or Bahia de Algeciras (Spa.) is the Bay of the Dry Elbow or "Gji-brryl-thari" (Shqip).

Lombardia (Ita.) - Lumbardhia - Lum-bardhi-a (Shqip) - The area of the White River - Lombardia is a province in the northwest of Italy, city-centered in Milano. (Lombardy, Wikipedia, 2019) "Lumbardh" or "Lumë $i$ Bardhë" (White River) or "I Bardhi" or "Bardhar" (The White [River]) are familiar names in Albanian lands. Lum-bardhi-a (Shqip) tells a broad region where the naturally-called "Lumi i Bardhe", (Shqip) - "The White River" passes through. The big river in northern Italy, which delineates the southern border of the province of Lombardia, is called River Po. It cannot be explained in Italian lan...gauge, while in Shqip is "Po" (Yes, Eng.). The White River (Lumbardhi, Shqip) is a river near the high mountains or Alpes. As such, it collects the water of the white snow. Therefore, it is called The White River-Lum-bardhi (shqip).

Trieste (Ita.) - Triështë - Tri është (Shqip) - Three is Trieste is a city at the Italian northern shore of the Adriatic Sea. Primarily, the town of Trieste built on three big hills. (Trieste, Wikipedia, 2019)

Etruria - E truri-a - Tru-ri-a - Etruria was in the centuries IX-VI B.C. a highly advanced region in the upper central and western part of Apennine Peninsula. The Roman culture sprouted from the Etruscan civilization. The Etruscan era ended with the establishment of the Roman Republic in 509 B.C. (Etruria, Wikipedia, 2019)

While this name has no explanation and meaning in the lan...gauges, it is a pure one-syllable name in Shqip (Speech): Tru (Brain). Also, in Shqip, the habitants of that region were called $E$-tru-skë, and as an adjective, the word is E-tru-ske. The river Albenia (Albegna, Ita.) flew/flows in the middle of that region.

The name Truri (The Brain) belongs to the dialect of southern Albania, and it is Truni for the northern dialect. As centuries went by and like an adjustment in usage, the Etruscans (Etruskët, Shqip) of the past got called Tuscī (Tuskë/Toskë, Shqip) and their heartland region Toscana (Toskanë, Shqip; Tuscany, Eng.). Simultaneously in Shqip, the southern part of Albania is still called Toskëri and its population Toskë, whereas the northern region is called Gegëri and its population Gegë. The Brain (Tru, Shqip) revived in Firenze, Toscana, in the century XIV. It peaked in the century XV and enlightened the Italian cultural Renaissance, which then gave light to the European Renaissance in the centuries XV-XVI.

Via Egnatia (Lat.) - Via/Vija Enjatia - Via/Vija E-njati-a (Shqip) - The Road Egnatia was a famous route constructed from Romans in the century II B.C. It started in Dyrrachium of Illyricum, continued through the Valley of Shkumbin River, past Macedonia and Thrace, and reached Byzantium (today Istanbul). (Via Egnatia, Wikipedia, 2019) "GN" in Latin and Italian pronounces exactly "NJ" as in Shqip. This means that Egnatia/Enjatia is a pure wordy clause in Shqip with the meaning of a noun. E njati (Shqip) translates [He] reached out, [he] made a stretch (Eng.). And, E njati-a (Shqip) is a noun that decodes "The Reaching Out" (Eng). It makes sense because Via Egnatia was a continuation on the 
eastern side of the Adriatic Sea of Via Appia that connected early Rome to Brundisium.

Next to Egnatia, the word Via (Lat.) = The Road (Ang.) is in Shqip because its root "Vi" is Shqip: Vi (Line, Ang.) and Via/Vija (The Line, Ang.). On the ground, Via (Lat.) is a Road (Ang.). Far above from the ground, Via (Lat.) or the Road (Ang.) is a Line ( $V i$, Shqip). Via Egnatia is still in existence and its name can be seen carved on stones. It is proof that the Speech (Shqip) was in use and Shqip-speaking scholars were around in those times.

Iónio Pélagos (Biz.) - Mar Ionio (Ita.) - Deti Ion - Deti Ionë/Jonë (Shqip) - Our Sea - This is the seas demarcated by southern Albania, western Greece, and southern Italy. In Greece, either the name "Ion" has no explanation, or a nonsense fairytale clothes it from antiquity. (Babiniotis, 2012) In Shqip, the word "Ion" is the possessive pronoun of "ionë/ jonë, $i$ ionë/jone" - our (Eng.). That is, the exact name of the Ionian Sea is Deti Ionë/Jonë (Shqip) - Our Sea (Eng).

Mer Tyrrhénienne (Fr.) - Mar Tirreno (Ita.) - Deti Tiren/ Tyren - Deti Tire-n / Tyre-n (Shqip) - This is the sea in the lower west coast of Italy and bordered by Sicily, Sardigna, and Corsica. Generally, the origin of this name gets extracted from a fairy-tale with antiquity nuance. It is about a Prince Tyrrhenus from Lydia (today Turkey) who settled together with his followers along the coast of Etruria. (Tyrrhenian Sea, Wikipedia, 2019)

In Shqip, this name is easily read and understood as Deti $i$ Tire or Deti Tiren after the southern Albanian dialect and Deti i Tyre or Deti Tyren after the northern Albanian dialect. All express "Their Sea". The toponyms of Our Sea (Deti Ion/ Ionë/Jonë, Shqip) and Their Sea (Deti Tyren/Tiren, Shqip) prove and complement one another. Because one sea is in the east and the other in the west of lower Italy. Furthermore, the root idiom of the people of Sardigna is called Arvareshu and is distinctly Shqip. (Mele, 2013; Mele, 2015; Mele, 2019)

Étretat (Fre.) - Etretat - E tretat (Shqip) - Of the Three Étretat is a coastal commune in the Seine-Maritime department in Normandy in north-western France. Étretat, part of the high rocky shoreline of Normandy, is well known for three big rocky arches falling to the ocean. (Étretat, Wikipedia, 2019) The name Étretat does not have any meaning for the local French people. In Shqip, Étretat is precisely the place of the three rocky arches, the site of the three, Étretat, E Tretat (Shqip).

Baltic Sea - Deti Baltik - Deti Balt-ik (Shqip) - The Muddy Sea - It is the sea outlined by Germany, Poland, Lithuania, Latvia, Estonia, Finland, and Sweden. Its shores are muddy and have many swamps. (Aber, 2016; Baltic Sea, Wikipedia, 2019) Therefore, the adjective "balt-ik" in Shqip depicts the very natural attribute of wetlands for the coast of this sea.

Danube River (Eng.) - I Shtrimi (Shqip) - It springs in Germany and, collecting vast amounts of water, flows flat southeast for $2850 \mathrm{~km}$ down to the Black Sea. It is navigable for $2415 \mathrm{~km}$ and, as such, it has been an established trade route since ancient times.

It appears with the name Ister on a map transmitted as of the date 450 B.C. and ascribed to a Persian named Herodotus of Halicarnassus (484 - 425 B.C.). The same name is also on a map transmitted as of the date 220 B.C. and credited to an African named Eratosthenes of Cyrene (276 - 195 B.C.). It retained the same name on the maps of the Roman Empire. For example, it was the upper border of the Prefecture of Illyricum on a map dated 395 A.D. The serotinous name of Danube seems adjusted in various lan...gauges. Many hypotheses are consisting of geographical and historical components that try to find meaning to past and present names of this river. (Danube, Wikipedia, 2019)

Since the characteristic of this river is the flat flow, it is said in Shqip: "Ky lum rrjedh shtruar" (This river flows flat). And therefore, it has been called since the beginning " $I$ Shtrimi", The Flat [-Flowing River].

\section{CONCLUSIONS}

The Speech (Shqip) is the oldest idiom in the EuroMediterranean area. Otherwise, it would have had, or others would have assigned a starting date for it. The Speech (Shqip) is so old that the written Euro-Mediterranean history accidentally distinguishes and proves it as the most ancient tongue. Since the Speech (Shqip) gets inherited too, the Shqip reborn fully after the Dark Ages.

The Speech (Shqip) can decode the many ancient writings carved on stone and pottery. Such as those claimed to represent "ancient Greek" lan...gauges or those of Sumer civilization of $4500-1900$ B.C.

It is proved that Nëfillimët (Nephilim) or Pjellargët, Tokarët, Arbërësit, Arbëreshët, Arbanasit, and Arvareshu are all words and wordy clauses in Shqip (Speech). All these names belong to the population of the beginning.

It is easily affirmed that wordy clauses in Shqip are part of the Shqip (The Speech) itself and carried in lan...guages. For instance, the Holy Bibles contain such words. In respect to Holy Bibles, it is not an issue that the religious books cannot fall in scientific resources, which is acceptable. What matters is what these very old books carry. And it means that more information can be mined from the epochs those books belonged to.

The wordy clauses in Shqip that are preserved anywhere in solid, grandiose, and eminent toponyms prove themselves because they express precisely the characteristics of their respective places.

On top of everything concluded above, it is a little to put into question whether "Ilirët" (Shqip) - Illyrians (Eng.) of the Illyric Peninsula were or were not "I Lirë" or "Të Lirë" (Shqip) - The Free or Free. (Wilkes, 1992) Aside from this, the more profound questions are of who called them "I-Lirë" (Shqip), who conveyed and how to the present days this name which is a modifying adjective, and what carries this name. The Holy Speech (Shqipen e Shenjtë, Shqip), the Heavenly Tongue (Gjuhën Hyjnore, Shqip).

\section{ACKNOWLEDGMENT}

The author embraces the honor to remember the precious communication with Robert Elsie, who passed away on 2 October 2017.

\section{REFERENCES}

Aber, J. S. (2016). Bogs and Mires of the Baltic Region with Examples from Estonia. Emporia State University. Re- 
trieved November 11, 2019, from http://academic.emporia.edu/aberjame/wetland/baltic/baltic.htm

Aegean Sea. (2019, August 20). Wikipedia. Retrieved November 11, 2019, from https://en.wikipedia.org/wiki/ Aegean_Sea

Babiniotis, $\bar{G}$. (2012). Lexiko tis Neoellinikis Glossas (Dictionary of Modern Greek Language), Athens: Kentro Lexikologias.

Baltic Sea. (2019, July 19) Wikipedia. Retrieved November 11, 2019, from https://en.wikipedia.org/wiki/Baltic_Sea

Book of Genesis. (2019, July 15). Wikipedia. Retrieved November 11, 2019, from https://en.wikipedia.org/wiki/ Book of Genesis

Carling, G. (2018, July 11). The Tocharians, the mysterious people that traveled more than $4000 \mathrm{~km}$ and ended up in a desert. Retrieved November 11, 2019, from https:// www.gerdcarling.se/2018/07/11/the-tocharians,-themysterious-people-that-travelled-more-than-4000-kmand-ended-up-in-a-desert-40064107

Cavalli-Sforza, L. L. (2000). Genes, Peoples and Languages, New York: North Point Press

Danube. (2019, July 16) Wikipedia. Retrieved November 11, 2019, from https://en.wikipedia.org/wiki/Danube

East India Company. (2019, August 16). Wikipedia. Retrieved November 11, 2019, from https://en.wikipedia. org/wiki/East India_Company

English Standard Version Bible. (2004). Bible Hub. Retrieved November 11, 2019, from https://biblehub.com/

Étretat. (2019, August 2) Wikipedia. Retrieved November 11, 2019, from https://en.wikipedia.org/wiki/\%C3\%89tretat

Etruria. (2019, August 29) Wikipedia. Retrieved November 11, 2019, from https:/en.wikipedia.org/wiki/Etruria

Fabius Planciades Fulgentius. (2019, September 3). Wikipedia. Retrieved November 11, 2019, from https://en.wikipedia.org/wiki/Fabius_Planciades_Fulgentius

Flower of Life Meaning, Origin, Application, Effect. (2016). Flower of Life. Retrieved November 11, 2019, from https://flower-of-life.net/

Gibraltar. (2019, August 29) Wikipedia. Retrieved November 11, 2019, from https://en.wikipedia.org/wiki/Gibraltar

Gómez-Torrente, M. (2018, September 6). Logical Truth. Stanford Encyclopedia of Philosophy. Retrieved November 11, 2019, from https://plato.stanford.edu/entries/logical-truth/

Hebrew Bible. (2019, July 9). Wikipedia. Retrieved November 11, 2019, from https://en.wikipedia.org/wiki/ Hebrew Bible

Hellas (theme). (2019, June 29). Wikipedia. Retrieved November 11, 2019, from https://en.wikipedia.org/wiki/ Hellas_(theme)

Hoffman, J. M. (1985). Hunza: Fifteen secrets of the healthiest and oldest living people, 5th Ed., Valley Center: Professional Press Publishing Association

Kimmelman, M. (2009, June 23). Elgin Marble Argument in a New Light. New York Times. https://www.nytimes. com/2009/06/24/arts/design/24abroad.html

Lolja, S. A. (2003, October 30). Hundëza and long-lived
Hunza people, Newspaper Panorama p. 12-13. (Alb.) http://www.albasoul.com/modules.php?op=modload $\&$ name $=$ News\&file $=$ article $\&$ sid $=954$

Lombardy. (2019, August 25) Wikipedia. Retrieved November 11, 2019, from https://en.wikipedia.org/wiki/Lombardy

Look, B. C. (2013, July 24). Gottfried Wilhelm Leibniz. Stanford Encyclopedia of Philosophy. Retrieved November 11, 2019, from https://plato.stanford.edu/entries/leibniz/

Malta. (2019, August 16) Wikipedia. Retrieved November 11, 2019, from https://en.wikipedia.org/wiki/Malta

Mediterranean Sea. (2019, May 18). Wikipedia. Retrieved November 11, 2019, from https://en.wikipedia.org/wiki/ Mediterranean_Sea

Mele, S. B. (2013, August 13). Arvareshu: Gjuha proto-sarde ilirike (Illyrian Pre-Sardignian Idiom). Voice of Albanians. Retrieved November 11, 2019, from www. voal-online.ch/index.php? $\bmod =$ article $\&$ cat $=$ SHQIPTAR $\%$ C3 $\% 8$ BT \& article $=36153$

Mele, S. B. (2015). Arvareshu: La Lingua Protosarda Ilirica Pelasgica e Etrusca, Sardigna: Logo Sardigna E-Book

Mele, S. B. (2019, April 27). Sardegna: Arvareshu, una lingua sorella dell'Albanese. YouTube. Retrieved November 11, 2019, from www.youtube.com/watch?v=Z6I7al5R3Ag\&feature=youtu.be

Natalis Comes. (2019, April 8). Wikipedia. Retrieved November 11, 2019, from https://en.wikipedia.org/wiki/ Natalis_Comes

Old Testament. (2019, July 15). Wikipedia. Retrieved November 11, 2019, from https://en.wikipedia.org/wiki/ Old_Testament

Orthodox Jewish Bible. (2004). Bible Hub. Retrieved November 11, 2019, from https://biblehub.com/

Roman Province. (2019, June 12). Wikipedia. Retrieved November 11, 2019, from https://en.wikipedia.org/wiki/ Roman province

Smith, J. (2013). The Book of Mormon, Salt Lake City: LDS Church Internet Ed.

Tiffou, E. (1993). Hunza Proverbs, Calgary: University of Calgary Press

Tocharians. (2019, June 22). Wikipedia. Retrieved November 11, 2019, from https://en.wikipedia.org/wiki/Tocharians

Trieste. (2019, August 23) Wikipedia. Retrieved November 11, 2019, from https://en.wikipedia.org/wiki/Trieste

Tyrrhenian Sea. (2019, July 20) Wikipedia. Retrieved November 11, 2019, from https://en.wikipedia.org/wiki/ Tyrrhenian Sea

Urim and Thummim (Latter Day Saints). (2019, July 5). Wikipedia. Retrieved November 11, 2019, from https:// en.wikipedia.org/wiki/Urim_and_Thummim_(Latter_ Day_Saints)

Via Egnatia. (2019, July 29) Wikipedia. Retrieved November 11, 2019, from https://en.wikipedia.org/wiki/Via_Egnatia Wilkes, J. J. (1992). The Illyrians, Massachusetts: Wiley-Blackwell

Xharra, F. (2019), Roma fliste Shqip, Prishtina: Lena 